\title{
Construction of a New Water Treatment System Based on Material Circulation
}

\author{
Ima Yudha Perwira, Takuji Hanashiro, Lutfi Nimatus Salamah, Dinesh Adhikari, \\ Kiwako S. Araki, Motoki Kubo*
}

Department of Biotechnology, Faculty of Life Sciences, Ritsumeikan University, Kusatsu, Shiga, Japan

Email: ${ }^{\star}$ kubo@sk.ritsumei.ac.jp

How to cite this paper: Perwira, I.Y., Hanashiro, T., Salamah, L.N., Adhikari, D., Araki, K.S. and Kubo, M. (2017) Construction of a New Water Treatment System Based on Material Circulation. Journal of Water Resource and Protection, 9, 1014-1025. https://doi.org/10.4236/jwarp.2017.98067

Received: May 10, 2017

Accepted: July 15, 2017

Published: July 18, 2017

Copyright $\odot 2017$ by authors and Scientific Research Publishing Inc. This work is licensed under the Creative Commons Attribution International License (CC BY 4.0).

http://creativecommons.org/licenses/by/4.0/

\begin{abstract}
A new water treatment system based on material circulation was constructed for purification of naturally polluted pond water in an aquarium. The water treatment system consisted of microbial columns with different flow rates ( 1.8 $\mathrm{L} / \mathrm{min} /$ column in 6-columns unit and $2.9 \mathrm{~L} / \mathrm{min} /$ column in 3-columns unit). Two hundred liters of water from a naturally polluted pond were treated for 14 days using the water treatment system. After treatment, the COD, TC, and TN had been reduced by up to $19.2 \%, 14.4 \%$, and $20.1 \%$, respectively. The bacterial biomass in the 3-columns unit was 7 -fold higher than that in the 6-columns unit, and PCR-DGGE analysis showed slightly different bacterial communities between the two columns $(<86 \%)$. The new water treatment system also worked efficiently in a fish-cultivated aquatic environment, with TC and TN removal rates of $190 \mathrm{mg} /$ week and $260 \mathrm{mg} /$ week, respectively.
\end{abstract}

\section{Keywords}

Water Treatment System, Material Circulation, 3-Columns Unit, 6-Columns Unit

\section{Introduction}

Oceans and rivers have a self-purification process that occurs through water circulation to maintain the organic matter load at a low level [1]. Through this process, organic materials in the water that are derived from anthropogenic activities [2] [3] and natural sources [4] [5] are decomposed to $\mathrm{CO}_{2}$ by aerobic bacteria (genus Bacillus, Pseudomonas, etc.) [6] [7], while nitrogen is removed through denitrification via microbial conversion of nitrate to $\mathrm{N}_{2}$ by $\alpha, \beta$, and $\gamma$ proteobacteria [8] [9].

However, limited water flow in lakes and ponds often causes inefficient 
self-purification [10]. Several experiments have attempted to solve this problem through various methods, such as the use of activated sludge, which supplies air for aerobic microorganisms to form a bacterial consortium to purify the water [11] [12], but such systems require high energy [13]. Slow-water circulation can be used to reduce carbon and nitrogen in water by allowing continuous contact between organic materials and environmental bacteria [14]. In addition, efficient water purification requires activation of both aerobic and anaerobic microorganisms to decompose organic materials in the aquatic environment [15].

This paper describes the development and construction of a new water treatment system based on material circulation by environmental microorganisms to purify water in a static water environment.

\section{Materials and Methods}

\subsection{Sampling Site and Water Sample}

The water sample used in this study was taken from a small pond (Kitanoshin Pond) located in Kusatsu, Shiga, Japan $\left(34^{\circ} 98^{\prime} \mathrm{N}, 135^{\circ} 96^{\prime} \mathrm{E}\right)$. A 200 liter water sample was taken from the pond every 14 days from 16 April 2014 to 16 February 2015.

\subsection{Construction of a New Water Treatment System Based on Material Circulation}

Before construction of the new water treatment system, the efficiencies of various treatments were evaluated in a preliminary experiment (20 L water tank). The treatments used were: water circulation with faster water flow rate columns (3-columns unit) and slower water flow rate columns (6-columns unit), circulation with 3-columns unit only, circulation with 6-columns unit only, circulation only, and control (without any treatment). The columns were filled with polyvinylalcohol (PVA) sponge and the COD removal rate was used to evaluate the efficiency of each treatment. The preliminary experiment showed that a combination of water circulation with 3-columns unit and 6-columns unit was most efficient (COD removal rate $>70 \%$ ). A new water treatment system was then constructed using a combination of water circulation with 3-columns unit and 6columns unit in a $200 \mathrm{~L}$ water tank.

\subsection{Experimental Period of the Water Treatment System}

The efficiency of the new water treatment system was evaluated by measuring COD, TC, and TN in a $200 \mathrm{~L}$ experimental tank. The measurement was performed from April 2014 to February 2015 throughout the spring (March to May), summer (June to August), autumn (September to November), and winter (December to February). The water was treated in the experimental tank for 14 days, after which it was exchanged with fresh water.

\subsection{Analysis of Water Quality}

Water quality parameters (COD, TC, and $\mathrm{TN})$ were analyzed during treatment. 
The COD was analyzed using the permanganate based titrimetric method [16]. Briefly, a $100 \mathrm{~mL}$ aliquot, $10 \mathrm{~mL}$ of diluted $\mathrm{H}_{2} \mathrm{SO}_{4}(48 \%), 10 \mathrm{~mL}$ of $5 \mathrm{mmol} / \mathrm{L}$ $\mathrm{KMnO}_{4}$, and $0.2 \mathrm{~g}$ of $\mathrm{Ag}_{2} \mathrm{SO}_{4}$ were mixed in an Erlenmeyer flask before digestion under heating at $90^{\circ} \mathrm{C}$. Next, $10 \mathrm{~mL}$ of $12.5 \mathrm{mmol} / \mathrm{L} \mathrm{Na}_{2} \mathrm{C}_{2} \mathrm{O}_{4}$ were added to the flask and mixed well. Finally, the remaining $\mathrm{Na}_{2} \mathrm{C}_{2} \mathrm{O}_{4}$ from the solution was de-

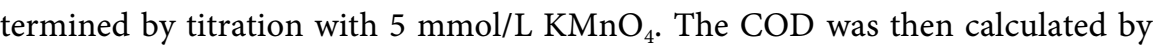
the formula:

$$
\mathrm{COD}(\mathrm{mg} / \mathrm{L})=(\mathrm{ml} \text { sample titration }- \text { ml blank titration }) \times 1 \times \text { dilution } \times 0.2
$$

where 1 is the $\mathrm{KMnO}_{4}$ factor in $5 \mathrm{~mol} / \mathrm{L}$ and 0.2 is the amount of oxygen in 5 $\mathrm{mol} / \mathrm{L} \mathrm{KMnO}_{4}$.

The COD removal rates were obtained through the formula:

$$
\text { COD removal rate }(\%)=\frac{\left(\mathrm{COD}_{0}-\mathrm{COD}_{14}\right)}{\mathrm{COD}_{0}} \times 100
$$

where $\mathrm{COD}_{0}$ is the value of $\mathrm{COD}$ before treatment and $\mathrm{COD}_{14}$ is the value of COD after treatment.

The TC and TN were measured using a total organic carbon analyzer (TOCVCPH, Shimadzu, Kyoto, Japan) and solid sample combustion unit (SSM-5000 A, Shimadzu, Kyoto, Japan) according to the manufacturer's instructions. Total phosphorus (TP) and total potassium (TK) in the water was analyzed by using molybdenum blue method [17]. Total potassium in water was analyzed by using atomic absorption spectrophotometer (Hitachi, Tokyo, Japan).

\subsection{Estimation of Total Bacteria}

The number of total bacteria in the microbial columns was measured from a sample collected from the PVA sponge filled in the 3-columns unit and 6-columns unit. Briefly, the slow-stirring method was used to extract the environmental DNA (eDNA) of bacteria [18]. Next, $1.0 \mathrm{~g}$ of wet PVA was mixed with 8 $\mathrm{ml}$ of DNA extraction buffer $(100 \mathrm{mmol} / \mathrm{L}$ tris-hydroxymethylaminomethane, $100 \mathrm{mmol} / \mathrm{L}$ sodium EDTA, $100 \mathrm{mmol} / \mathrm{L}$ sodium phosphate, $1.5 \mathrm{mmol} / \mathrm{L} \mathrm{NaCl}$, $1 \%$ hexadecylmethylammonium bromide) and $1.0 \mathrm{~mL} 20 \%(\mathrm{w} / \mathrm{v})$ sodium dodecyl sulfate (SDS) solution. The suspension was then mixed using a propeller (1500 rpm) under constant agitation for 20 minutes at room temperature before centrifugation at $6000 \times \mathrm{g}$ for 10 minutes. Next, $700 \mu \mathrm{L}$ of supernatant was transferred into a $1.5 \mathrm{~mL}$ microtube, mixed with chloroform-isoamylalcohol mixture $(24: 1(\mathrm{v} / \mathrm{v}))$ in equal volume, and centrifuged at $18,000 \times \mathrm{g}$ for 10 minutes. The aqueous phase $(500 \mu \mathrm{L})$ was subsequently mixed with $300 \mu \mathrm{l}$ of isopropanol to precipitate the pellet of crude nucleic acids by centrifuging the mixture at 18,000 $\times \mathrm{g}$ for 20 minutes. After drying, the pellet was rinsed with $1 \mathrm{ml}$ of $70 \%$ ethanol and dissolved in $50 \mu \mathrm{l}$ of TE buffer (Tris/EDTA $=10: 1 \mathrm{mmol} / \mathrm{L}$ ). The extracted eDNA was quantified based on the intensity of eDNA bands generated during $1 \%$ agarose gel electrophoresis using the KODAK 1D 3.6 Image Analysis Software (Kodak, CT, USA). 


\subsection{Amplification of $16 \mathrm{~S}$ rRNA Bacterial Gene}

The 16S rRNA bacterial gene was amplified using primers DGGE-F (5'-CGCCC GCCGC GCCCC GCGCC CGTCC CGCCG CCCCC GCCCG CCTAC GGGAG GCAGC AG-3') and DGGE-R (5'-CCGTC AATTC CTTTG AGTTT-3') [19]. The amplification reaction was carried out in a $50 \mu \mathrm{L}$ PCR mixture containing $0.01 \mathrm{ng} / \mu \mathrm{L}$ of DNA template, $1.5 \mathrm{U}$ rTaq DNA polymerase, $5.0 \mu \mathrm{L}$ of $10 \times$ buffer, $5.0 \mu \mathrm{l}$ of $2 \mathrm{mM}$ dNTPs, $3.0 \mu \mathrm{l}$ of $\mathrm{MgCl}_{2}$ and $2.0 \mu \mathrm{L}$ of $10 \mathrm{mmol} / \mathrm{L}$ of each primer. DNA polymerase, dNTPs and PCR buffer were purchased from Toyobo (Toyobo Co. Ltd., Osaka, Japan), while all primers were synthesized by Sigma-Aldrich (Sigma-Aldrich, Tokyo, Japan). The thermal PCR profile was as follows: initial denaturation at $95^{\circ} \mathrm{C}$ for $1 \mathrm{~min}$, followed by 35 cycles of denaturation at $95^{\circ} \mathrm{C}$ for $1 \mathrm{~min}$, primer annealing at $55^{\circ} \mathrm{C}$ for $30 \mathrm{sec}$, and extension at $72^{\circ} \mathrm{C}$ for $1 \mathrm{~min}$ and then final extension at $72^{\circ} \mathrm{C}$ for $5 \mathrm{~min}$. Finally, the amplified $16 \mathrm{~S}$ rRNA bacterial genes were used for denaturing gradient gel electrophoresis (DGGE) analysis.

\subsection{DGGE Analysis}

DGGE was performed using a D Code System (BioRad Laboratories Inc., California, USA). A total of $20 \mu \mathrm{l}$ of PCR product were loaded into $40 \%(\mathrm{w} / \mathrm{v})$ polyacrylamide gel with a denaturant gradient of $27.5 \%-67.5 \%$. The gel was then run in $1 \times$ tris-acetate EDTA buffer at a constant voltage of $70 \mathrm{~V}$ at $60^{\circ} \mathrm{C}$ for 15 hours. Next, the gel was stained using SYBR Gold for $20 \mathrm{~min}$, then rinsed with distilled water. Cluster analysis of the DGGE band pattern was subsequently conducted using the FPquest Bioinformatics Software (BioRad Laboratories Inc., California, USA).

\subsection{Analysis of Carbon and Nitrogen in a Fish-Cultivated Environment Using the New Water Treatment System}

The new water treatment system was evaluated in water containing high levels of organic materials in a fish tank. A tank containing $200 \mathrm{~L}$ of tap water, $20 \mathrm{~kg}$ of sand sediment, and 12 goldfish maintained at room temperature $\left(25^{\circ} \mathrm{C}\right)$ was used in the experiment. The experiment was divided into two stages: before operation of the microbial columns (stage I) and after the operation of the microbial columns (stage II). Stage I was conducted for 21 weeks, and stage II for 18 weeks. Fish were fed $0.5 \mathrm{~g}$ fish feed (TC: 300,000 mg/kg and TN: 45,000 mg/kg) every day. Thus, the total carbon input during the experiment was $40,950 \mathrm{mg}$ (22,050 $\mathrm{mg}$ in stage I and 18,900 $\mathrm{mg}$ in stage II), and the nitrogen input was 6140 $\mathrm{mg}$, with $3310 \mathrm{mg}$ in stage I and 2830 in stage II. The amounts of TC and TN (in $200 \mathrm{~L}$ of water and $20 \mathrm{~kg}$ of sediment) at the beginning and at the end of stage I and stage II were measured to analyze their mass balance (input and accumulation). The differences in TC and TN accumulation in $\mathrm{CO}_{2} / \mathrm{N}_{2}$ and goldfish between stage I and stage II were used to analyze the removal efficiency of TC and TN. Finally, the removal rate of TC and TN in the environment during treatment was analyzed based on the removal efficiency value. 


\section{Results}

\subsection{Construction of a New Water Treatment System Based on Material Circulation and Activated Environmental Microorganisms}

A new water treatment system was constructed using water circulation and activated aerobic and anaerobic microorganisms. The schematic diagram of the new water treatment system is shown in Figure 1. This system consists of two units of microbial columns with a $200 \mathrm{~L}$ water tank, and each unit has a different water flow rate. A stainless steel microbial column $347 \mathrm{~mm}$ in length with a $52 \mathrm{~mm}$ inner diameter was prepared and filled with $770 \mathrm{ml}$ of PVA sponge. The first unit had six parallel columns, while the second had three parallel columns. The first unit provided a lower water flow rate $(1.8 \mathrm{~L} / \mathrm{min} /$ column$)$, and the water circulation was 13 cycles/day. The flow rate of the second unit was $2.9 \mathrm{~L} / \mathrm{min} /$ column, and the water circulation was 21 cycles/day. The first (column with slower water flow rate) and the second units (faster flow rate) were defined as 6 columns unit and 3-columns unit, respectively. The faster water flow rate seems to provide relatively higher aeration in the 3-columns unit. Similarly, slower water flow rate might have provided relatively low aeration in the 6-columns unit. The water was passed through both columns units and went back to the tank, where the water was mixed and recirculated to the both columns units, separately.

\subsection{Efficiency of the New Water Treatment System for Treating Water from a Natural Pond}

Water used in this study was taken from Kitanoshin Pond, Shiga, Japan $\left(34^{\circ} 98^{\prime} \mathrm{N}\right.$,

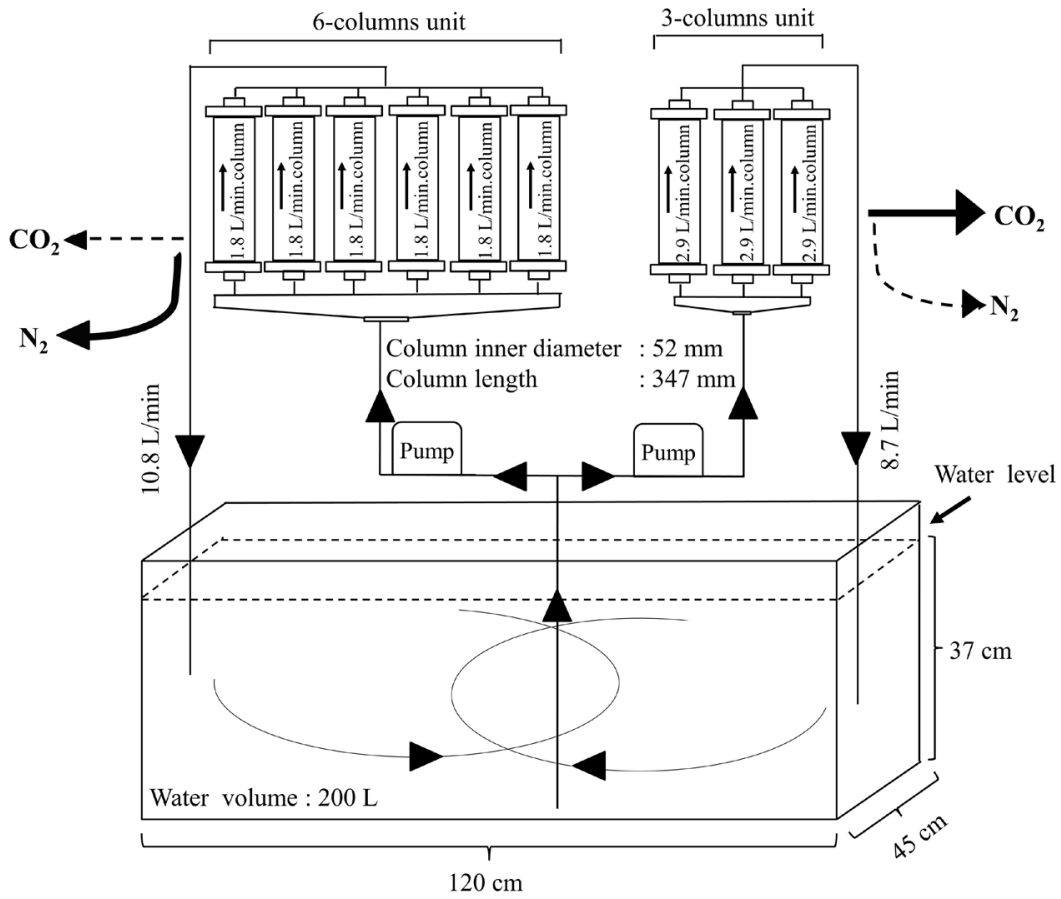

Figure 1. Schematic diagram of the new water treatment system based on material circulation. Black arrow represents the direction of water flow in the system. 
$\left.135^{\circ} 96^{\prime} \mathrm{E}\right)$. The COD, TC, and TN values in all seasons are shown in Table 1. Analysis of the water showed that the average TC $(4.7 \mathrm{mg} / \mathrm{L})$ was 10 times higher than that of the TN $(0.41 \mathrm{mg} / \mathrm{L})$, indicating high carbon biomass in the water. The average COD during all seasons was $5.6 \mathrm{mg} / \mathrm{L}$, which was still higher than the standard for agricultural use in Japan $(<5 \mathrm{mg} / \mathrm{L})$.

The water was treated using the new water treatment system to evaluate the efficiency of this system to reduce COD, TC, and TN in the water. The COD, TC, and TN removal rates were reduced in all seasons (Table 1). The COD removal rate increased from spring $(7.5 \%)$ to summer $(24.6 \%)$, after which the removal rates became stable from autumn (23.0\%) to winter (21.7\%). A similar tendency was observed in the TC and TN removal rates. The average removal rates of COD, TC, and TN were $19.2 \%, 14.4 \%$, and $20.1 \%$, respectively, during all seasons. These results indicate that environmental bacteria together with water flow led to constant and efficient purification of the pond water.

Table 1. Values of COD, TC, TN in the water and their removal rates during the 14 day treatment period (experiments were carried out from 16 April 2014 to 16 February 2015).

\begin{tabular}{|c|c|c|c|c|c|c|c|c|c|c|c|c|c|}
\hline \multirow[b]{2}{*}{ Season } & \multirow[b]{2}{*}{ Date } & \multicolumn{4}{|c|}{ COD } & \multicolumn{4}{|c|}{ TC } & \multicolumn{4}{|c|}{$\mathrm{TN}$} \\
\hline & & $\begin{array}{c}\text { Day 0 } \\
(\mathrm{mg} / \mathrm{L})\end{array}$ & $\begin{array}{l}\text { Day } 14 \\
(\mathrm{mg} / \mathrm{L})\end{array}$ & $\begin{array}{l}\text { Removal } \\
\text { rate }(\%)\end{array}$ & $\begin{array}{l}\text { Average } \\
\text { removal } \\
\text { rate (\%) }\end{array}$ & $\begin{array}{c}\text { Day 0 } \\
(\mathrm{mg} / \mathrm{L})\end{array}$ & $\begin{array}{l}\text { Day 14 } \\
(\mathrm{mg} / \mathrm{L})\end{array}$ & $\begin{array}{c}\text { Removal } \\
\text { rate (\%) }\end{array}$ & $\begin{array}{l}\text { Average } \\
\text { removal } \\
\text { rate }(\%)\end{array}$ & $\begin{array}{l}\text { Day 0 } \\
(\mathrm{mg} / \mathrm{L})\end{array}$ & $\begin{array}{l}\text { Day } 14 \\
(\mathrm{mg} / \mathrm{L})\end{array}$ & $\begin{array}{l}\text { Removal } \\
\text { rate }(\%)\end{array}$ & $\begin{array}{l}\text { Average } \\
\text { removal } \\
\text { rate (\%) }\end{array}$ \\
\hline \multirow{3}{*}{ Spring } & April 16 & 3.4 & 3.4 & 0.0 & & 3.5 & 3.5 & 0.0 & \multirow{3}{*}{0.7} & 0.1 & 0.1 & 0.0 & \multirow{3}{*}{18.0} \\
\hline & May 1 & 3.2 & 3.2 & 0.0 & 7.5 & 3.5 & 3.5 & 0.0 & & 0.3 & 0.2 & 34.4 & \\
\hline & May 16 & 4.0 & 3.1 & 22.5 & & 4.9 & 4.8 & 2.0 & & 0.4 & 0.3 & 37.5 & \\
\hline \multirow{6}{*}{ Summer } & June 1 & 3.8 & 3.2 & 15.8 & \multirow{6}{*}{24.6} & 5.9 & 4.3 & 27.1 & & 0.3 & 0.3 & 0.0 & \multirow{6}{*}{28.0} \\
\hline & June 16 & 5.0 & 3.0 & 40.0 & & 5.7 & 4.1 & 28.1 & & 0.8 & 0.1 & 81.8 & \\
\hline & July 1 & 8.1 & 7.1 & 12.4 & & 5.6 & 5.2 & 7.1 & & 0.4 & 0.4 & 0.0 & \\
\hline & July 16 & 8.0 & 5.8 & 27.5 & & 6.2 & 5.7 & 8.1 & 20.5 & 0.6 & 0.3 & 49.2 & \\
\hline & August 1 & 6.1 & 5.2 & 14.8 & & 5.4 & 4.7 & 13.0 & & 0.6 & 0.6 & 0.0 & \\
\hline & August 16 & 8.1 & 5.1 & 37.0 & & 6.8 & 4.1 & 39.7 & & 0.5 & 0.3 & 37.0 & \\
\hline \multirow{6}{*}{ Autumn } & September 1 & 6.6 & 5.1 & 22.7 & \multirow{6}{*}{23.0} & 5.0 & 4.7 & 6.0 & & 0.3 & 0.3 & 0.0 & \multirow{6}{*}{12.8} \\
\hline & September 16 & 13.4 & 10.4 & 22.4 & & 7.1 & 5.6 & 21.1 & & 0.7 & 0.6 & 6.2 & \\
\hline & October 1 & 8.5 & 6.0 & 29.4 & & 5.5 & 4.5 & 18.2 & & 0.8 & 0.4 & 54.4 & \\
\hline & October 16 & 6.5 & 4.8 & 26.2 & & 5.2 & 3.6 & 30.8 & & 0.3 & 0.3 & 16.1 & \\
\hline & November 1 & 6.7 & 4.9 & 26.9 & & 4.7 & 3.4 & 27.7 & & 0.3 & 0.3 & 0.0 & \\
\hline & November 16 & 4.3 & 4.3 & 0.0 & & 3.8 & 3.5 & 7.9 & & 0.5 & 0.5 & 0.0 & \\
\hline \multirow{5}{*}{ Winter } & December 1 & 2.8 & 1.9 & 33.2 & & 3.3 & 1.9 & 42.4 & & 0.4 & 0.2 & 47.5 & \multirow{5}{*}{21.5} \\
\hline & December 16 & 2.0 & 2.0 & 0.0 & & 2.1 & 2.1 & 0.0 & & 0.3 & 0.3 & 0.0 & \\
\hline & January 16 & 3.7 & 2.0 & 46.0 & 21.7 & 2.8 & 2.2 & 21.4 & 17.8 & 0.3 & 0.2 & 40.7 & \\
\hline & February 1 & 3.3 & 3.3 & 0.0 & & 2.6 & 2.3 & 11.5 & & 0.3 & 0.2 & 19.2 & \\
\hline & February 16 & 4.4 & 3.1 & 29.6 & & 2.9 & 2.5 & 13.8 & & 0.3 & 0.3 & 0.0 & \\
\hline Average & & & & & 19.2 & & & & 14.4 & & & & 20.1 \\
\hline
\end{tabular}




\subsection{Analysis of Bacterial Number and Diversity in the Columns}

The total bacteria in both 3-columns unit and 6-columns unit were analyzed for environmental DNA (Figure 2). During the experiment, the average total number of bacteria in the 3-columns unit was almost six times higher $\left(1.4 \times 10^{9}\right.$ cells/g-wet PVA) than that in the 6-columns unit $\left(2.5 \times 10^{8}\right.$ cells/g-wet PVA). Similarly, the bacterial diversities of the 3-columns unit and 6-columns unit were below $86 \%$, but the bacterial diversity among 3-columns unit and 6-columns unit was above $90 \%$ (Figure 3). These results indicate that the difference

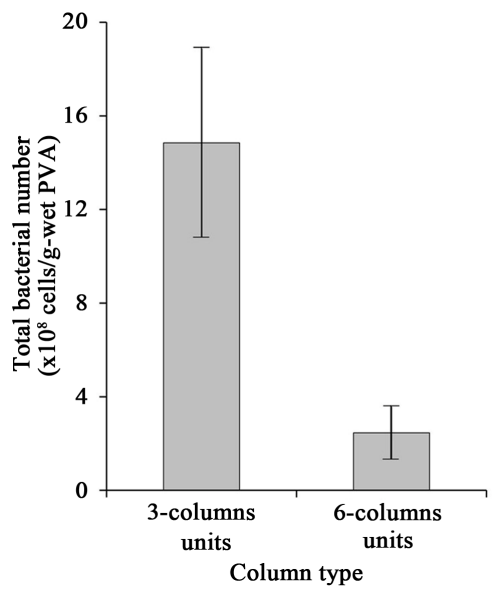

Figure 2. Total bacteria in the 3-columns unit and 6-columns unit.

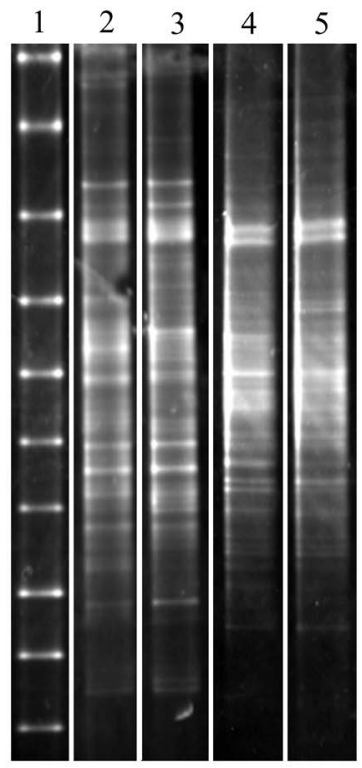

(a)

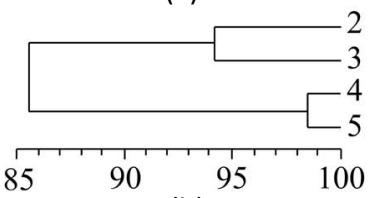

(b)

Figure 3. PCR DGGE analysis of $16 \mathrm{~S}$ rRNA bacterial genes: image of electrophoresis (1: Marker; 2 - 3: 3-columns unit; and 4 - 5: 6-columns unit) (a) and cluster analysis (b). 
in water flow rate in the columns led to supply of different aerobic conditions. The faster water flow rate in the 3-columns unit appears to supply oxygen to enhance the total bacterial number. Different bacterial diversities were also shown in 3-columns unit and 6-columns unit owing to differences in oxygen level.

\subsection{Effect of the Water Treatment System in a Fish-Cultivated Aquatic Environment}

The new water treatment system was used for evaluation of water treatment in a fish-cultivated aquatic environment. Before starting the operation (stage I), 22,050 $\mathrm{mg}$ of carbon and $3310 \mathrm{mg}$ of nitrogen were added into the environment by fish feed (Table 2). During stage I, the carbon accumulation in the water and sediment were $1850 \mathrm{mg}$ and $4000 \mathrm{mg}$, respectively. In the case of nitrogen, 1270 $\mathrm{mg}$ was accumulated in the water and $1800 \mathrm{mg}$ was accumulated in the sediment. Figure 4 shows the increase in TC and TN in the water and sediment with the addition of fish feed.

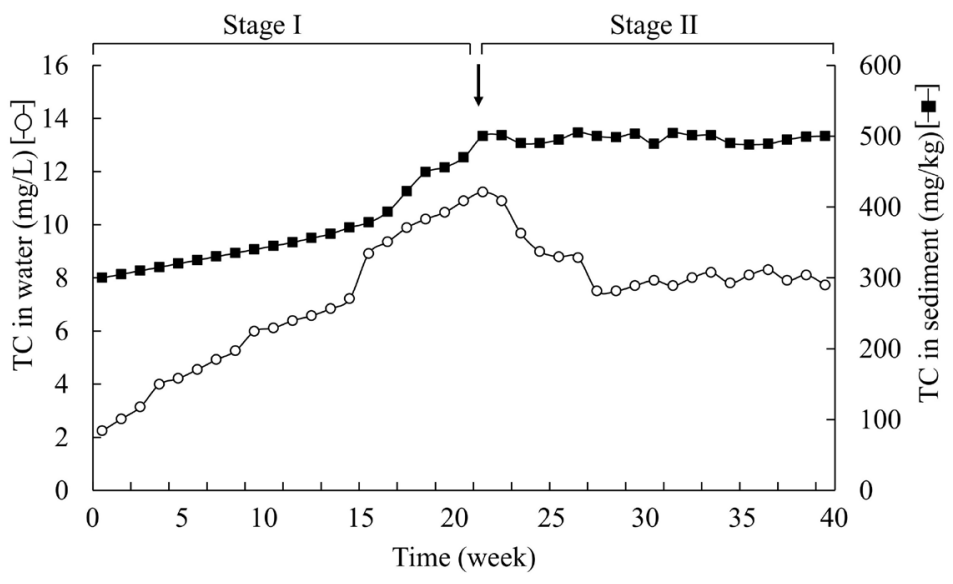

(a)

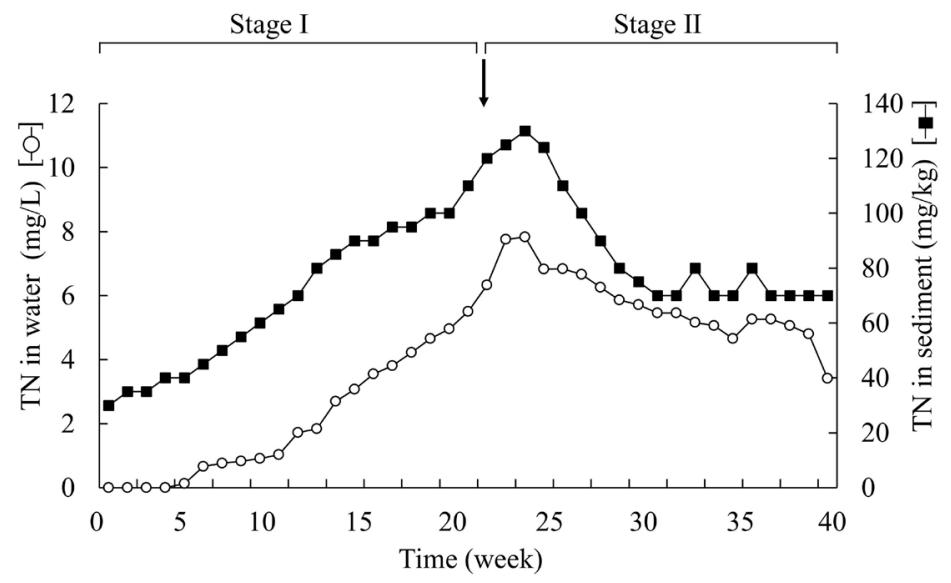

(b)

Figure 4. Concentration of TC and TN in the water and sediment during treatment in the fish-cultivated aquatic environment: TC (a) and TN (b). Black arrow represents the starting time of the new water treatment system operation. 
Table 2. Mass balance of TC and TN during treatment of a fish-cultivated aquatic environment.

\begin{tabular}{cccccccccc}
\hline & \multicolumn{4}{c}{ Stage I } & \multicolumn{3}{c}{ Stage II } \\
\cline { 2 - 9 } Parameter & $\begin{array}{c}\text { Input } \\
(\mathrm{mg})\end{array}$ & Water Sediment & $\begin{array}{c}\mathrm{CO}_{2} / \mathrm{N}_{2} \text { and } \\
\text { accumulation } \\
\text { in fish }\end{array}$ & $\begin{array}{c}\text { Input } \\
(\mathrm{mg})\end{array}$ & Water & Sediment & $\begin{array}{c}\mathrm{CO}_{2} / \mathrm{N}_{2} \text { and } \\
\text { accumulation } \\
\text { in fish }\end{array}$ \\
\hline TC & 22,050 & 1850 & 4000 & 16,200 & 18,900 & -700 & 0 & 19,600 \\
TN & 3310 & 1270 & 1800 & 240 & 2830 & -880 & -1200 & 4910 \\
\hline
\end{tabular}

The new water treatment system was operated to purify the water after 21 weeks (stage II). During stage II, there was no accumulation of carbon and nitrogen in either the water or sediment (Table 2). The removal rates of TC and $\mathrm{TN}$ in the water and sediment during stage II are shown in Table 3 . The removal values of TC and TN during stage II were $3400 \mathrm{mg}$ and $4670 \mathrm{mg}$, respectively, which was about $190 \mathrm{mg} /$ week and $260 \mathrm{mg} /$ week, respectively. These results suggest that the amounts of carbon and nitrogen in the water and sediment were efficiently reduced after using the new water treatment system.

The accumulation of TC and TN during the experiment (stages I and II) was analyzed (Figure 5). From a total 40,950 $\mathrm{mg}$ of carbon input (22,050 $\mathrm{mg}$ in stage I and $18,900 \mathrm{mg}$ in stage II), the accumulation in the water and the sediment was $2.8 \%$ and $9.8 \%$, respectively ( $87.4 \%$ was removed as $\mathrm{CO}_{2}$ and/or accumulated in the fish). In the case of TN, $6.4 \%$ was accumulated in the water and $9.8 \%$ was accumulated in the sediment (83.9\% was removed as $\mathrm{N}_{2}$ and/or accumulated in the fish). These results indicate that the new water treatment system efficiently removed TC and TN, even in the fish-cultivated aquatic environment.

\section{Discussion}

A new water treatment system based on material circulation was constructed for purification of water in a natural static environment. The system was designed based on a water flow environmental self-purification mechanism [1]. The system consisted of two pumps that contributed to environmental bacterial immobilization and water circulation without filtration [20]. Water in the aquarium was circulated ( 34 cycles/day) by the system at a rate faster than that of Lake Biwa (ancient lake) in Japan [21]. The microbial immobilization and water circulation by the system appeared to efficiently improve the values of COD and TC and lead to stabilization of the TN level in the water.

Enhanced aerobic and anaerobic bacteria accelerated the carbon and nitrogen removal in the water through several processes [6] [9]. Removal of TC to $\mathrm{CO}_{2}$ by the system was attributed to the decomposition of organic materials by aerobic bacteria in the columns. Similarly, TN removal was associated to the anaerobic bacteria in the 6-columns unit. The difference in bacterial community structure as shown in Figure 3 might be due to the different aeration in the columns. The bacterial number in the columns was higher than that in wetland environments [22], indicating that the system had a high capacity to decompose organic mate- 


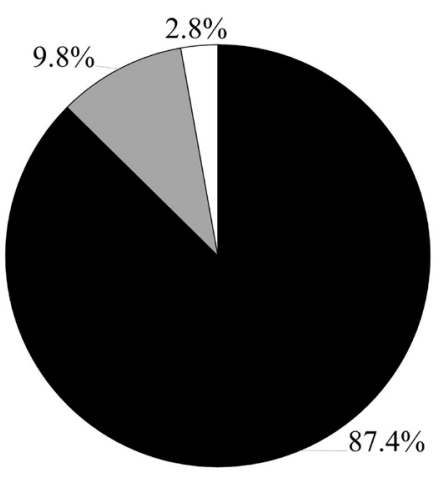

- $\mathrm{CO}_{2}$ and fishes $\square$ in sediment $\square$ in water

(a)

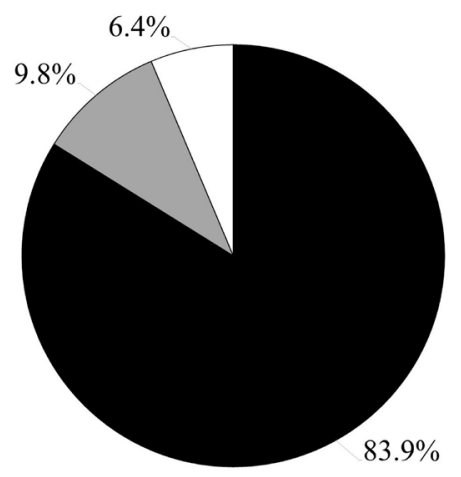

$\mathrm{N}_{2}$ and fishes $\square$ in sediment $\square$ in water

(b)

Figure 5. Accumulation of TC and TN in the water and sediment during treatment in the fish-cultivated aquatic environment: TC (a) and TN (b).

Table 3. Mass balance of TC and TN during treatment of a fish-cultivated aquatic environment.

\begin{tabular}{ccccc}
\hline \multirow{2}{*}{ Parameter } & \multicolumn{2}{c}{$\mathrm{CO}_{2} / \mathrm{N}_{2}$ and accumulation in fish } & $\begin{array}{c}\text { Total removal value } \\
\text { by the system }(\mathrm{mg})\end{array}$ & $\begin{array}{c}\text { Removal value in a week } \\
\text { by the system }(\mathrm{mg})\end{array}$ \\
\cline { 2 - 3 } Stage I & Stage II & 19,600 & 3400 & 190 \\
TC & 16,200 & 4910 & 4670 & 260 \\
\hline
\end{tabular}

rials in the aquatic environment. The new water treatment system also worked efficiently in a fish-cultivated aquatic environment, and the nitrogen removal rate became higher. The high nitrogen concentration in the aquatic environment may stimulate activation of denitrifying bacteria in the 6-columns unit [23]. Although we did not analyze the denitrification and nitrification activities in this study, but successful reduction of nitrogen indicates that the denitrification was taken place in the system.

Use of activated sludge system is one of the extensively used methods for treating polluted water. Activated sludge system carries both aerobic and anaerobic tanks, but it requires huge energy [11]. The new water treatment system also carries both aerobic and anaerobic microbial columns, but the system does not require high energy and large space. Therefore, the system seems to be suitable for water treatments of natural pond and lake with lower energy. In a study of treating fish-pond water using water circulation system, TN level was about $10 \mathrm{mg} / \mathrm{L}$ [24]. But our system using water circulation and microbial columns with different water flow rates provided TN level less than $5 \mathrm{mg} / \mathrm{L}$. The system successfully removed carbon and nitrogen from the water, but accumulations of phosphorus and potassium were observed in the fish-cultivated aquatic environment ( 0 to $0.5 \mathrm{mg} / \mathrm{L}$ and 0 to $10 \mathrm{mg} / \mathrm{L}$, respectively). Addition of mechanisms for removal of phosphorous and potassium will be needed in the system; therefore, a new machine to accomplish this is currently being developed. 


\section{References}

[1] Cazelles, B., Fontvieille, D. and Chau, N.P. (1991) Self-Purification in a Lotic Ecosystem: A Model of Dissolved Organic Carbon and Benthic Microorganisms Dynamic. Ecological Modelling, 58, 91-117. https://doi.org/10.1016/0304-3800(91)90031-U

[2] Grizzetti, B., Pretato, U., Lassaletta, L., Billen, G. and Garnier, J. (2013) The Contribution of Food Waste to Global and European Nitrogen Pollution. Environmental Science and Policy, 33, 186-195. https://doi.org/10.1016/j.envsci.2013.05.013

[3] Bouraoui, F. and Grizzetti, B. (2014) Modeling Mitigation Options to Reduce Diffuse Nitrogen Water Pollution from Agriculture. Science of the Total Environment, 468-469, 1267-1277. https://doi.org/10.1016/j.scitotenv.2013.07.066

[4] Schindler, D.W., Bayley, S.E., Curtis, P.J., Parker, B.R., Stainton, M.P. and Kelly, C.A. (1992) Natural and Man-Caused Factors Affecting the Abundance and Cycling of Dissolved Organic Substances in Precambrian Shield Lakes. Hydrobiologia, 229, 1-21. https://doi.org/10.1007/BF00006987

[5] Meili, M. (1992) Sources, Concentrations and Characteristics of Organic Matter in Softwater Lakes and Streams of the Swedish Forest Region. Hydrobiologia, 229, 23 41. https://doi.org/10.1007/BF00006988

[6] Jonsson, A., Meili, M., Bergstrom, A.-K. and Jansson, M. (2001) Whole-Lake Mineralization of Allochthonous and Autochthonous Organic Carbon in a Large Humic Lake (Ortrasket, N. Sweden). Limnology and Oceanography, 46, 1691-1700. https://doi.org/10.4319/lo.2001.46.7.1691

[7] Orji, F.A., Dike, E.N., Lawal, A.K., Sadiq, A.O., Suberu, Y., et al. (2016) Properties of Bacillus Species Cellulase Produced Using Cellulose from Brewers Spent Grain (BSG) as Substrate. Advances in Bioscience and Biotechnology, 7, 142-148. https://doi.org/10.4236/abb.2016.73013

[8] Rodríguez, D.C., Ramírez, O. and Mesa, G.P. (2011) Behavior of Nitrifying and Denitrifying Bacteria in a Sequencing Batch Reactor for the Removal of Ammoniacal Nitrogen and Organic Matter. Desalination, 273, 447-452. https://doi.org/10.1016/j.desal.2011.01.068

[9] Pei, Y.S., Wang, J., Wang, Z.Y. and Yang, Z.F. (2010) Characteristics of AmmoniaOxidizing and Denitrifying Bacteria at the River-Sediment Interface. Procedia Environmental Sciences, 2, 1988-1996. https://doi.org/10.1016/j.proenv.2010.10.214

[10] Winter, T.C. (1999) Relation of Streams, Lakes, and Wetlands to Groundwater Flow Systems. Hydrogeology Journal, 7, 28-45. https://doi.org/10.1007/s100400050178

[11] Wilén, B.-M., Keiding, K. and Nielsen, P.H. (2004) Flocculation of Activated Sludge Flocs by Stimulation of the Aerobic Biological Activity. Water Research, 38, 39093919.

[12] Souza, S.M., Araújo, O.Q.F. and Coelho, M.A.Z. (2008) Model-Based Optimization of a Sequencing Batch Reactor for Biological Nitrogen Removal. Bioresource Technology, 99, 3213-3223.

[13] Hreiz, R., Latifi, M.A. and Roche, N. (2015) Optimal Design and Operation of Activated Sludge Processes: State-of-the-Art. Chemical Engineering Journal, 281, 900 980.

[14] Huang, J.-S., Chou, H.-H., Chen, C.-M. and Chiang, C.-M. (2007) Effect of Recycle to Influent Ratio on Activities of Nitrifiers and Denitrifiers in a Combined UASBActivated Sludge Reactor System. Chemosphere, 68, 382-388.

[15] Jena, J., Kumar, R., Saifuddin, Md., Dixit, A. and Das, T. (2016) Anoxic-Aerobic SBR System for Nitrate, Phosphate and COD Removal from High-Strength Waste- 
water and Diversity Study of Microbial Communities. Biochemical Engineering Journal, 105, 80-89.

[16] Kawabe, M. and Kawabe, M. (1997) Temporal and Spatial Characteristics of Chemical Oxygen Demand in Tokyo Bay. Journal of Oceanography, 53, 19-26. https://doi.org/10.1007/BF02700745

[17] American Public Health Association (APHA) (1992) Standard Methods for the Examination of Water and Wastewater. 18th Edition, American Public Health Association, Washington DC.

[18] Aoshima, H., Kimura, A., Shibutani, A., Oakada, C., Matsumiya, Y., et al. (2006) Evaluation of Soil Bacterial Biomass Using Environmental DNA Extracted by SlowStirring Method. Applied Microbiology and Biotechnology, 71, 875-880. https://doi.org/10.1007/s00253-005-0245-x

[19] Adhikari, D., Mukai, M., Kubota, K., Kai, T., Kaneko, N., et al. (2016) Degradation of Bioplastic in Soil and their Degradation Effects on Environmental Microorganisms. Journal of Agricultural Chemistry and Environment, 5, 23-24. https://doi.org/10.4236/jacen.2016.51003

[20] Shin, G.-A., Kim, T.-Y., Kim, H.-S., Maeng, M.-S. and Dockko, S. (2016) Membrane Hybrid System Combined with a Trickling Filter and a Thin Layer of Biosand to Reduce High Level of Organic Matter in Drinking Water in Developing Countries. Process Safety and Environmental Protection, 104, 541-548.

[21] Akitomo, K., Tanaka, K. and Kumagai, M. (2009) Annual Cycle of Circulations in Lake Biwa, Part 2: Mechanisms. Limnology, 10, 119-129. https://doi.org/10.1007/s10201-009-0268-6

[22] Faulwetter, J.L., Gagnon, V., Sundberg, C., Chazarenc, F., Burr, M.D., et al. (2009) Microbial Processes Influencing Performance of Treatment Wetlands: A Review. Ecological Engineering, 35, 987-1004.

[23] Sakai, K., Ikehata, Y., Ikenaga, Y., Wakayama, M. and Moriguchi, M. (1996) Nitrite Oxidation by Heterotrophic Bacteria under Various Nutritional and Aerobic Conditions. Journal of Fermentation and Bioengineering, 82, 613-617.

[24] Konnerup, D., Trang, N.T.D. and Brix, H. (2011) Treatment of Fishpond Water by Recirculating Horizontal and Vertical Flow Constructed Wetlands in the Tropics. Aquaculture, 313, 57-64.

Submit or recommend next manuscript to SCIRP and we will provide best service for you:

Accepting pre-submission inquiries through Email, Facebook, LinkedIn, Twitter, etc. A wide selection of journals (inclusive of 9 subjects, more than 200 journals)

Providing 24-hour high-quality service

User-friendly online submission system

Fair and swift peer-review system

Efficient typesetting and proofreading procedure

Display of the result of downloads and visits, as well as the number of cited articles

Maximum dissemination of your research work

Submit your manuscript at: http://papersubmission.scirp.org/

Or contact jwarp@scirp.org 